\title{
DE CPN EN DE ZENDTIJD VOOR POLITIEKE PARTIJEN
}

Tot september 1965 was de CPN uitgesloten van de 'door de regering ten behoeve van de politieke partijen gevorderde zendtijd'. Omdat de CPN het bestaande politieke systeem principieel afwees, vond de regering met de meerderheid van de Tweede Kamer dat zij geen actieve bijdrage hoefde te leveren aan de verspreiding van de communistische propaganda. Door de opkomst van de televisie en daarmee gepaard gaande maatschappelijke en culturele veranderingen werd dit standpunt steeds moeilijker vol te houden, al deed de BvD nog wel verwoede pogingen om de regering van een koerswijziging af te brengen.

$\mathrm{Na}$ de Tweede Wereldoorlog krijgen politieke partijen aanvankelijk alleen zendtijd op de radio in de periode voorafgaande aan de verkiezingen. Dit gebeurt op basis van een aparte ministeriële regeling voor het eerst bij de verkiezingen in 1948. In dat jaar nemen de communisten de macht over in Tsjecho-Slowakije en deze gebeurtenis betekent een keerpunt in de verhoudingen tussen de communistische partijen en de andere partijen in Nederland en alle andere westerse landen. Hoewel minister Gielen van Onderwijs, Kunsten en Wetenschappen het jaar daarvoor nog positief reageerde op een motie van de communist Wagenaar om alle partijen zendtijd te geven, wordt de CPN van begin af aan als enige politieke partij uitgesloten. In de motivering daarvoor verwijst minister Gielen rechtstreeks naar de gebeurtenissen in TsjechoSlowakije:

'Men kan van een democratisch volk en een democratische regering na de verklaring die de leider van de communisten ten aanzien van de gebeurtenissen in Tsjecho-Slowakije heeft afgelegd niet verwachten dat zij buiten de rechten die in de Grondwet zijn gewaarborgd aan een partij als de CPN de gelegenheid geeft tot propaganda. ${ }^{\mathrm{I}}$

De druk op de regering om veel verder te gaan met maatregelen tegen de CPN (KVP-voorman Romme bepleitte zelfs een verbod) is in die dagen groot, maar juristen komen met veel bezwaren. ${ }^{2}$ Het onthouden van zendtijd wordt niet gezien als het onthouden van een recht maar van een gunst. En gunsten hoef je je vijand niet te geven, zo was de redenering.

In de aanloop naar de verkiezingen van ${ }_{195} 6$ lijkt er bij de regering (minister Cals) enige ruimte te komen voor een koerswijziging. ${ }^{3}$ De dreiging van een com- 
KRUIMELS IN HET DAGELIJKSE

TELEVISIEGEWELD.

Uit de CPN-TVuitzending van 10-2-1967. Fre Meis spreekt na afloop van een $C P N$ demonstratie in Groningen. Bron: B. Hogenkamp/ P. Mol, Van beeld tot beeld,

Amsterdam 1993

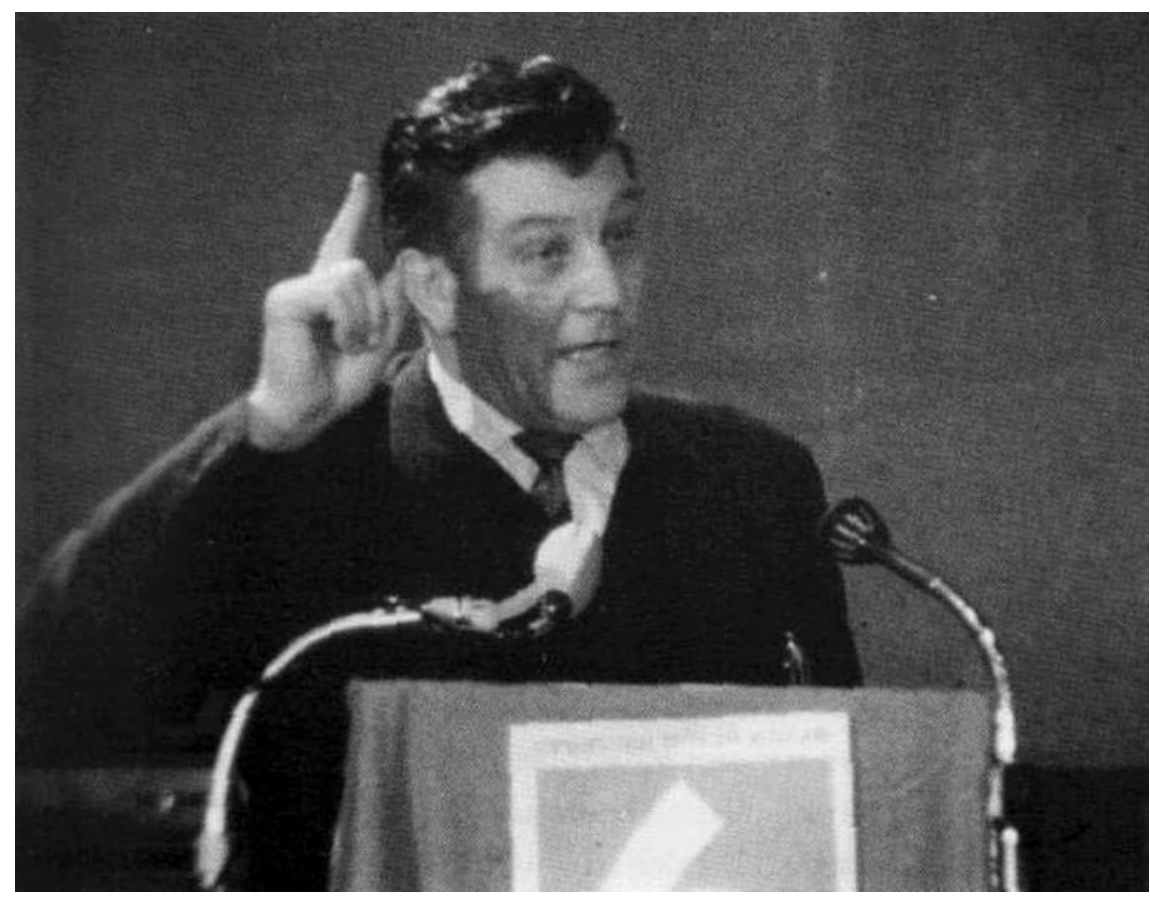

munistische aanval uit de jaren daarvoor is wat weggeëbd. Toch blijft de cP N uiteindelijk uitgesloten van de zendtijd 'om principiële redenen'. ${ }^{4}$ Groot is echter de verontwaardiging als een extreemrechtse partij, de nou (Nederlandse Oppositie Unie), aanvankelijk wél wordt toegelaten. Onder de kop 'Fascisten in uw huiskamer' schrijft Marcus Bakker op de voorpagina van De Waarheid een vlammend artikel over de onbeschaamdheid van de regering die fascisten een podium biedt terwijl verzetsstrijders (lees: communisten) de mond wordt gesnoerd. Dit keer krijgt de CPN enige steun, onder andere van de liberale $N R C$ en van het sociaal-democratische Kamerlid Hilda Verwey-Jonker. Cals heeft het er moeilijk mee. Gelukkig voor hem kan hij de Nou alsnog uitsluiten omdat er iemand met een oorlogsverleden op de lijst staat van wie het passief en actief kiesrecht is ontnomen. ${ }^{5}$ Vanwege het antifascistische sentiment kan de CPN haar eigen uitsluiting wel ter discussie stellen, maar zendtijd levert het vooralsnog niet op. Ook een jaar later, als de zendtijd opnieuw aan de orde komt omdat de regering de politieke partijen ook buiten verkiezingstijd zendtijd wil gaan geven, blijft de CPN uitgesloten. De inval van de Sovjet-Unie in Hongarije, eind I956, en de daarop volgende aanval op с Р N'ers en с Р N-bezittingen zullen daarbij ongetwijfeld meegespeeld hebben. De lichte dooi in de koude oorlog vanwege het optreden van Chroestjow is snel voorbij. 
In de jaren zestig komen er nieuwe kansen voor de CPN als de televisie doorbreekt in de Nederlandse huiskamer. Tussen I957 en I967 vertienvoudigt het percentage geregistreerde televisietoestellen in Nederlandse huishoudens. ${ }^{6}$ Elk jaar komt er meer uitzendtijd bij, in I964 een tweede net.

De televisie zorgt voor grote veranderingen in de massacommunicatie. Het nieuwe medium maakt veel indringender dan de radio mensen getuige van belangrijke politieke gebeurtenissen (de moord op Kennedy bijvoorbeeld). Een nieuwe generatie journalisten doorbreekt de wat bezadigde wijze van communiceren die bij het radiotijdperk hoorde en verlegt de grenzen van vorm en inhoud.

Televisie brengt ook de parlementaire politiek op een nieuwe manier in de huiskamer. Vanaf het najaar I962 komen er op de Nederlandse televisie regelmatig live-reportages uit de Tweede Kamer. ${ }^{8}$ Daarin komen uiteraard ook vertegenwoordigers van de CPN in beeld. De CPN, die, met uitzondering van de Nou-kwestie, tot dan toe niet zo veel ophef heeft gemaakt over het onthouden van zendtijd, grijpt dit gegeven aan voor een interpellatie in januari ig63. In de Tweede Kamer eist Marcus Bakker vanwege de aanwezigheid van de CPN in de live-reportages ook officieel zendtijd voor zijn partij. Hij stelt zich achter alle vrijheden van de Nederlandse grondwet en hij zegt dat de CPN geen kopie wil van het socialisme in de Sovjet-Unie. ${ }^{9}$ Het mag niet baten. De regering handhaaft haar oude standpunt op oude gronden.

Opmerkelijk in het debat bij deze interpellatie is wel dat Bakker niet alleen steun krijgt van de PS P-afgevaardigde Noordenbos, maar ook van Mevrouw Van Someren Downer van de vvd, toen nog regeringspartij. Zij wijst naast principiële bezwaren met Bakker op de inconsequentie die voortvloeit uit het feit dat de CPN wel aan het woord komt in uitzendingen van Kamerdebatten, maar als enige niet in de officiële zendtijd voor politieke partijen. ${ }^{\text {.० }}$

\section{De CPN en de media}

De Koude Oorlog en haar stellingname daarin hebben de CPN sinds het einde van de jaren veertig steeds verder geïsoleerd. Hoezeer de partij zich ook probeert te profileren als een Nederlandse communistische partij, in het klimaat van de Koude Oorlog makkt de Oost-West tegenstelling een partij die nadrukkelijk het 'Oosten' steunt bij veel mensen verdacht. Aan het begin van de jaren zestig staat een groot deel van de Nederlandse samenleving vijandig tegenover de partij, die ook steeds meer in zichzelf gekeerd raakt. De partij heeft haar eigen media die de aanhang een geheel eigen visie op de werkelijkheid en de dagelijkse actualiteit geven. Een ander geluid dringt daarin nauwelijks door, net zo min als andere bevolkingsgroepen in hun media geïnformeerd worden over de standpunten van de CPN. In deze zin past de CPN keurig in het plaatje van de verzuilde 
samenleving waarin de toppen van de zuilen de media domineren en er op toezien dat de concurrentie zo veel mogelijk buiten de deur gehouden wordt.

De televisie, de ontzuiling en de politieke en culturele vernieuwing in de jaren zestig maken langzamerhand een eind aan deze hokjesgeest en gaandeweg ook aan het isolement van de CPN. De partij krijgt in elk geval meer mogelijkheden om zich via de media aan het volk te presenteren. Dat is wel wennen, omdat de vijandige gevoelens over en weer nog niet direct verdwenen zijn.

In mei I963 nodigt de NTs de CPN uit op de verkiezingsavond commentaar te komen geven op de uitslag. Het dagelijks bestuur van de partij reageert verontwaardigd met een telegram aan minister-president De Quay (omdat de partij pas 'na het sluiten van de stembussen' het woord krijgt) en eist zendtijd voor de volgende week dinsdag na het NTs-journaal, het gebruikelijke tijdstip voor de uitzendingen van de politieke partijen. Joop Wolff wordt wel afgevaardigd naar de NTs-verkiezingsavond. ${ }^{\text {II }}$

De CPN-leiding grijpt echter nog niet meteen alle mogelijkheden aan om in de niet-communistische media te verschijnen. In I963 lezen we in de notulen van het dagelijks bestuur afwijzende reacties op verzoeken om een interview door De Telegraaf en het Algemeen Handelsblad. ${ }^{\text {I2 }}$ In I964 wijst Marcus Bakker een optreden in het tv-programma ZO IS HET TOEVALLIG OOK NOG EENS EEN KEER af. Kennelijk is er enige correspondentie aan vooraf gegaan. In de afwijzingsbrief reageert Bakker op de introductie die de redactie voor hem in petto heeft. Herman Wigbold stelt voor hem als volgt aan te kondigen: 'In communistische landen krijgen tegenstanders geen gelegenheid om hun standpunt voor tv te verkondigen, bij ons moet die vrijheid er wel zijn.' Bakker schrijft na overleg met het D в terug dat hij er voor past in een kader op te treden waarin de socialistische landen verdacht worden gemaakt en het eigen systeem verheerlijkt. Verder merkt hij op dat als voorstanders van Verwoerd en Salazar (rechtse dictators in resp. Zuid-Afrika en Portugal) 'oningelijst' kunnen spreken, dat hij zich zo'n vernederende introductie niet wil laten welgevallen. ${ }^{\mathrm{I3}}$

Een jaar later wijst het dagelijks bestuur nog een verzoek af van het NCRVtelevisieprogramma ATTE NTIE, ook al zou het interview juist gaan over het toekennen van zendtijd aan de CPN. ${ }^{\text {I4 }}$

\section{De strijd om een nieuw omroepbestel}

Vanaf het eind van de jaren vijftig wordt de drang vanuit het bedrijfsleven om de media commerciëel te kunnen exploiteren steeds groter. De welvaart stijgt, de consumptiemaatschappij is in aantocht, maar de bijbehorende ruimte voor reclame laat lang op zich wachten. Het gat wordt gevuld door zogenaamde piratenzenders die vanaf schepen op de Noordzee populaire muziekprogramma's uitzenden (radio Veronica). Ook is er kortstondig een tv-piraat waaruit later de nieuwe omroep tros zal ontstaan. Het oude omroepbestel met de traditionele 


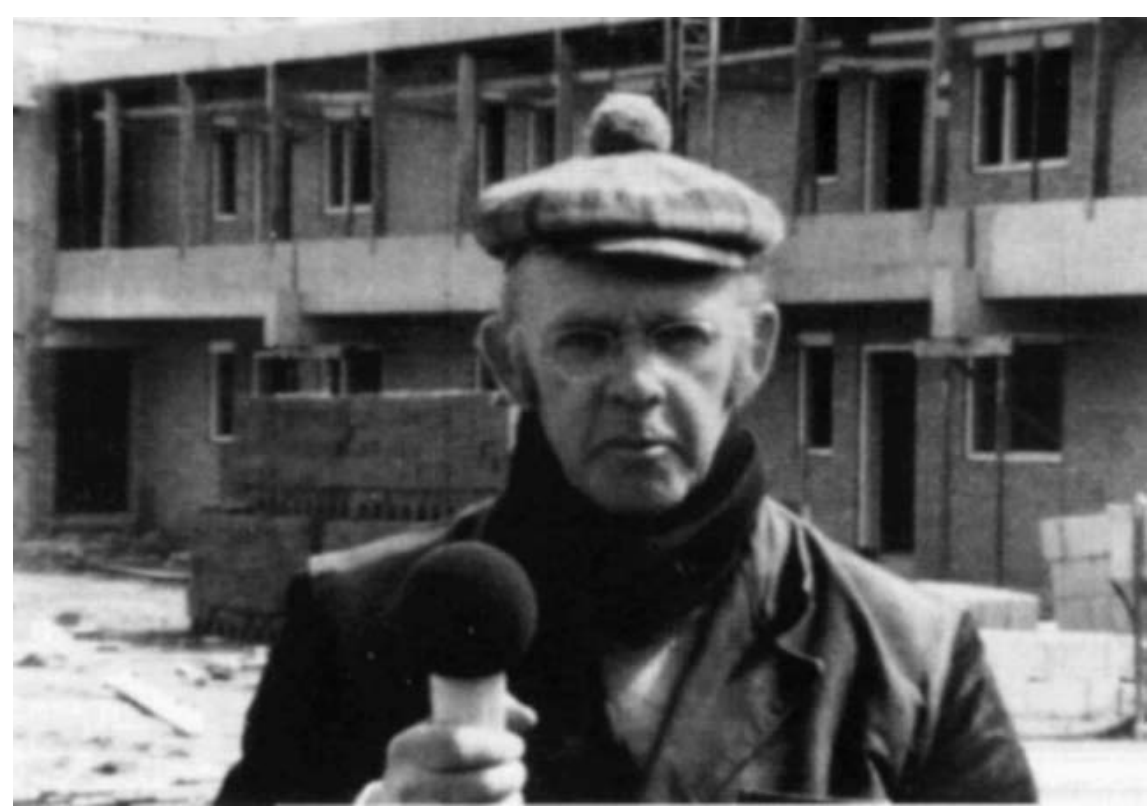

zuilen op basis van religie en ideologie wankelt en de noodzakelijke vernieuwing leidt tot een heftige strijd. Grote spanningen ontstaan in de coalities van de christelijke partijen (verbonden met de zuilen) en de vvo (verbonden met de commercie). In 1963 haalt een wetsvoorstel van de regering-De Quay het niet door een meerderheid van christelijke partijen en PvdA; in I965 struikelt het kabinet-Marijnen over de omroeppolitiek. Het daarna geformeerde kabinetCals, waarbij de christelijke partijen de vvD inruilen voor de PvdA, lukt het in I967 uiteindelijk wel een nieuwe omroepwet (het 'open bestel') door de Kamer te loodsen.

In deze context komt ook de zendtijd voor politieke partijen weer aan de orde, misschien niet het meest spannende onderdeel van de nieuwe wetgeving, maar wel met één lastig punt: de zendtijd voor de C PN. Lastig, omdat een meer definitieve regeling van de zendtijd in een nieuwe omroepwet politieke partijen rechten zou geven. En het uitsluiten van een recht is moeilijker te verdedigen dan - zoals tot dan toe steeds de redenering was - het onthouden van een gunst. Zeker nu in de publieke opinie het tij langzamerhand keert van een gesloten zuilencultuur naar een meer open politieke cultuur.
Bouwvakker Wim Hans spreekt op lokatie voor een CPN-uitzending, april 1970. Bron: B. Hogenkamp/ P. Mol, Van beeld tot beeld, Amsterdam 1993

\section{De BVD waarschuwt}

In de besluitvorming over de toekenning van zendtijd aan de CPN doet ook de Binnenlandse Veiligheidsdienst (BVD) van zich horen. De BVD neemt daarbij afstand van de naar tolerantie neigende opvattingen van politici en waarschuwt 
de regering voor het communisme dat gevaarlijk blijft voor de Nederlandse staat en het democratische bestel.

Al in I96r, bij de toewijzing van zendtijd voor de televisie, heeft de BVD de regering met succes gewaarschuwd voor het gevaar van de CPN onder verwijzing naar een recent gepubliceerd partijprogramma van de Russische communistische partij waarin de dictatuur van het proletariaat als doel is opgenomen. ${ }^{15} \mathrm{De}$ regering handhaaft dan nog het oude standpunt, maar in I963 lijkt daar een kentering in te komen en daarbij komt de veiligheidsdienst opnieuw in actie.

In het najaar van I963 richt de nieuwe minister van o K\& w, Bot (KVP), zich tot de minister-president (Marijnen, KVP). In de verwachting dat de zendtijdkwestie bij de algemene beschouwingen aan de orde zal komen, en met verwijzing naar de discussie bij de interpellatie van Marcus Bakker aan het begin van dat jaar, zet hij een aantal argumenten pro en contra op een rij. Enerzijds wijst hij op de mogelijke botsing tussen de vrijheid van meningsuiting en de bescherming van de grondslagen van de democratische staatsvorm. En hij herhaalt het oude standpunt dat de vrijheid van meningsuiting ook voor de CPN voldoende is gewaarborgd door deze partij niets in de weg te leggen bij de verspreiding van haar standpunten via andere middelen, maar dat van de regering niet verlangd mag worden dat zij in positieve zin gelegenheid biedt door van staatswege zendtijd ter beschikking te stellen. Anderzijds wijst Bot, met het vvd-Kamerlid Van Someren Downer, op de inconsequentie van het tot dan gevoerde beleid. Als deze partij niet verboden wordt en verder alle rechten geniet die andere partijen ook hebben, is het dan niet inconsequent om op één punt een uitzondering te maken? Bot werpt de vraag op of het gevaar wel zo groot is en of het uiteindelijk niet nadeliger zal zijn als de CPN in een underdogpositie blijft zitten. De regering heeft toch middelen om in te grijpen als het uit de hand loopt. En mogen we niet vertrouwen op de politieke mondigheid van de burgers en de stabiliteit van ons democratisch systeem? Voor een politieke verschuiving bij de kiezers hoeft echt niet gevreesd te worden als de CPN zendtijd krijgt, 'omdat na korte tijd zal blijken dat men de communistische praatjes op waarde schat'. ${ }^{\text {'6 }}$

De juridisch adviseur van de minister-president wijst er op dat Bot in deze brief een ander geluid laat horen dan staatssecretaris Scholten namens de vorige regering in zijn antwoord op de interpellatie van Marcus Bakker. In zijn bijdrage aan de standpuntbepaling stelt de adviseur dat het zonder meer verlenen van gelijke rechten aan minderheden 'te rechtlijnig, te democratisch-dogmatisch is geredeneerd'. Als zendtijd wordt verleend aan de CP N zal dat niet zonder condities moeten gebeuren. Er moet een weg terug zijn als er moeilijkheden komen. De adviseur noemt ook verzachtende omstandigheden, ontleend aan de actualiteit: de vreedzame coëxistentie, het kernstopverdrag, de nationale koers van de CPN en de toekenning van de PC Hooftprijs (een staatsprijs) aan de communistische schrijver Theun de Vries. ${ }^{17}$

De BVD is kennelijk niet gerust op een goede afloop. Op 9 oktober I963 vindt een gesprek plaats met de politiek verantwoordelijke minister van Binnen- 
landse Zaken (Toxopeus, vvd). De dag erop krijgt hij het standpunt van de dienst op schrift. 'Het communisme is een even grote bedreiging als vroeger'. De CP N zal zendtijd gebruiken voor het ondergraven van de Nederlandse democratische staatsvorm. Het toestaan aan de CPN van meer mogelijkheden voor propaganda dan de thans reeds door deze partij gebruikte middelen overschrijdt de grens die aan deze intolerante partij gesteld moet worden. Indien men zendtijd zou willen toewijzen zou er een 'escapeclausule' moeten worden ingebouwd voor het geval de partij bijvoorbeeld buitensporig gaat groeien. In de praktijk is dat echter onmogelijk. ${ }^{\mathrm{I}}$

Het kabinet schuift op II oktober de zaak nog even voor zich uit. Minister Bot krijgt te horen dat in zijn notitie een conclusie ontbreekt op basis waarvan het kabinet een standpunt kan bepalen. ${ }^{\text {I9 }}$

Op 23 oktober stuurt Bot een nieuwe brief. Hij heeft alles nog eens afgewogen en komt uiteindelijk tot een afwijzend standpunt. Doorslaggevend daarbij is een nog niet eerder genoemd tegenargument: de CPN is in feite geen Nederlandse partij, maar een zetbaas van een buitenlandse regering.

In de ministerraad van 25 oktober blijkt dit argument met name de minister van Defensie, de Jong (KVP) zeer aan te spreken. Toxopeus (VvD), de minister van Binnenlandse Zaken zegt in deze vergadering dat hij het nog niet aandurft om 'de discriminatie van de CPN' te beëindigen vanwege de aard en het optreden van deze partij. Anderen sluiten zich daarbij aan. Bot zelf heeft het er nog steeds moeilijk mee. Waarom de PSP wel en de CPN niet? Alleen Biesheuvel (AR) vindt de argumenten om de CPN wel zendtijd te geven sterker dan de argumenten om haar die zendtijd te onthouden. De minister-president concludeert dat de CPN op grond van de huidige nota geen zendtijd krijgt toegewezen. Minister Van Aartsen (VvD) voegt daar nog de suggestie aan toe om niet te veel nieuwe argumenten bij dit besluit te noemen en gewoon vast te houden aan de oude motivering. ${ }^{20}$

\section{De minister wijzigt zijn standpunt}

$\mathrm{Na}$ het stranden van een nieuwe omroepwet onder het kabinet-De Quay zet de regering Marijnen zich in de jaren 1964 en 1965 aan een nieuwe poging. Met het oog op het nieuwe omroepbeleid kaart Bot opnieuw ook de kwestie van de toekenning van zendtijd aan de CPN aan. In februari I965, als de spanningen hoog oplopen omdat het kabinet beloofd heeft uiterlijk I maart een nieuw wetsvoorstel te presenteren, schrijft hij een nieuwe notitie aan de ministerraad. Hij stelt aan zijn collega's de vraag: is het kwaad dat aangericht wordt door de CPN zendtijd toe te kennen groter dan wel kleiner dan de weigering? En hij formuleert nu wel een duidelijke conclusie. Gelet op de toelating van enkele nieuwe partijen en het huidige standpunt van welhaast alle in het parlement vertegenwoordigde partijen meent hij dat de CPN nu wel zendtijd zou moeten krijgen. ${ }^{21}$ 
Een week later heeft de BVD een scherp afwijzend standpunt klaar voor de minister van Binnenlandse Zaken. Politici, schrijft de dienst, relativeren onder invloed van de publieke opinie de ernst van de zaak. Men verwijst naar de beginselen van de vreedzame coëxistentie. 'De communistische wereld daarentegen relativeert nimmer'. Dat parlementariërs zich beroepen op een sterke democratie (die het gevaar kan keren) vindt de schrijver van deze BvD-notitie begrijpelijk.

'Ik vraag mij echter af of niet de Regering, aan welke de veiligheid van de staat is toevertrouwd, tegen dit gemakkelijke aanvaarden van dat risico de eigen taak van de uitvoerende macht primair moet stellen. En ik meen inderdaad dat hier de tolerantie behoort te wijken voor het niet denkbeeldige gevaar dat de CPN met behulp van de zeer aansprekende media - en met enige goede sprekers - zal uitgroeien tot een omvang dat zij een pressure group kan worden'.22

Luister niet naar het parlement, zegt de BVD met andere woorden. Maar, terwijl de dienst krampachtig vasthoudt aan de voortdurende dreiging uit het Oosten als argument tegen zendtijd voor de CPN, neigen politici inmiddels naar een meer pragmatische opstelling.

\section{Een kwestie van opportuniteit}

Het kabinet komt er niet uit met de nieuwe omroepwet en biedt eind februari zijn ontslag aan. De zendtijd voor de CPN is niet meer aan de orde geweest.

Er komt nu - zonder verkiezingen - een nieuw kabinet onder leiding van Cals (KvP), met de PvdA. Op 7 mei komt Bots notitie alsnog aan de orde, nu onder verantwoordelijkheid van de minister van C R M (Cultuur, Recreatie en Maatschappelijk Werk) Vrolijk (PvdA). Deze gaat met een nieuwe nota Radio- en Televisiebeleid een derde poging doen om de omroepstrijd te beëindigen. Inzake de zendtijd voor de CPN sluit hij zich aan bij Bots conclusie: de uitsluiting van de CPN is niet meer te verantwoorden. Hij noemt dit een kwestie van opportuniteit. 'Als men ziet wat de Boerenpartij zich in deze uitzendingen permitteert acht spreker uitsluiting van de CP N niet in evenredigheid'. ${ }^{23}$ Hij wijst er verder op dat in België de communistische partij ook zendtijd heeft. Minister van Verkeer \& Waterstaat Suurhoff (PvdA) heeft een minder pragmatische benadering. Hij meent dat een principiële antidemocraat geen morele aanspraken kan maken op democratische rechten. De Boerenpartij van Koekoek is geen gevaar, meent hij, de CPN echter is als een ijsberg, het grootste gevaar is onzichtbaar. De Jong (Kv P, Defensie) stelt opnieuw dat het hier gaat om een zetbaas van Moskou en Peking en daarom is gelijke behandeling zijns inziens geen deugdelijk argument. Luns (Kv , Buitenlandse Zaken) wijst op het gevaar van belediging van bevriende staatshoofden. Dit was in die dagen een actueel punt 
omdat in demonstraties tegen de oorlog in Vietnam de Amerikaanse president Johnson een moordenaar werd genoemd. Smallenbroek, de minister van Binnenlandse Zaken, blijft bij het oude standpunt. Het verlenen van zendtijd is een positieve daad, niet te vergelijken met het verlenen van spreektijd in het parlement. De CPN houdt zich naar zijn mening niet aan de democratische spelregels. Zij wil met de vrijheid die ze krijgt vrijheid vernietigen. Hij acht het hoe dan ook onverstandig om direct na het aantreden van het kabinet met zo'n maatregel te komen.

Vondeling en Den Uyl ondersteunen Vrolijk en vinden het geen principiële kwestie. Het is niet meer uit te leggen aan jongeren, meent Vondeling. Uitsluiting van de CPN leeft niet sterk meer in het rechtsbewustzijn van de bevolking, meent Den Uyl. De laatste vraagt zich overigens wel af of elke partij wel evenveel zendtijd zou moeten krijgen, ongeacht de omvang van de vertegenwoordiging in het parlement. In dat geval is hij geneigd tegen het voorstel te stemmen. Vrolijk voelt wel wat voor een verdeling naar grootte. Hij reageert ook positief op de suggestie van Vondeling om de CPN maar helemaal niet meer te noemen in een nieuw zendtijdbesluit (het gaat uiteindelijk om het omroepbeleid en niet om de CPN). Een positief besluit jegens de CPN zit er kennelijk niet in. Diepenhorst (AR), de minister van Onderwijs, bepleit het opnemen van een passage in de nota over het omroepbeleid waarin de regering duidelijk maakt dat zij niet zal terugschrikken voor verbreking van de uitzending indien daarin normen worden geschonden die partijen ook in het parlement in acht moeten nemen.

Minister-president Cals concludeert aan het einde van de discussie dat de CPN 'over enige tijd' zendtijd krijgt, dat een zinsnede zoals Diepenhorst heeft voorgesteld zal worden opgenomen en dat de minister een voorstel uitwerkt om de zendtijd naar grootte van de partijen te verdelen. Op 2I mei komt de Nota Vrolijk opnieuw in de ministerraad en dan blijken de AR-ministers Biesheuvel en Smallenbroek moeite te hebben met dit laatste punt, omdat hierover niets is afgesproken in het nieuwe regeringsakkoord. Vondeling en Den Uyl leggen zich hierbij neer. ${ }^{24}$ Een week later wil Diepenhorst toch nog meer duidelijkheid over een eventueel ingrijpen in de uitzendingen als een partij (lees: de CPN) over de schreef gaat. Minister van Justitie Samkalden is tegen preventief ingrijpen, maar weet Diepenhorst gerust te stellen met de formulering: 'Als tijdens de uitzending blijkt dat men staatsgevaarlijke onderwerpen wil bespreken dan zal de knop van de zender worden omgedraaid, ${ }^{25}$ Hij verwijst hierbij naar de kwestie Bidault. De KRO zag in die dagen 'vrijwillig' af van uitzending van een interview met de omstreden Franse oud-minister Bidault, nadat de regering duidelijk had gemaakt dat men de knop zou omdraaien om de relaties met Frankrijk niet te verstoren.

Van BVD-adviezen aan de nieuwe regering is in deze fase geen spoor meer te vinden. Of het zou het standpunt van Smallenbroek, de minister van Binnenlandse Zaken en als zodanig baas van de BvD, moeten zijn, die aan het einde van alle discussies in de notulen laat aantekenen dat hij tegen het besluit is om de CPN zendtijd te geven. 
Paul de Groot spreekt ter ere van de veertigste verjaardag van de Oktoberrevolutie in het Leninstadion te Moskou, november 1957. Bron: Jan Willem Stutje, De man die de weg wees. Leven en werk van Paul de Groot I899 - I986, De Bezige Bij,

Amsterdam 2000

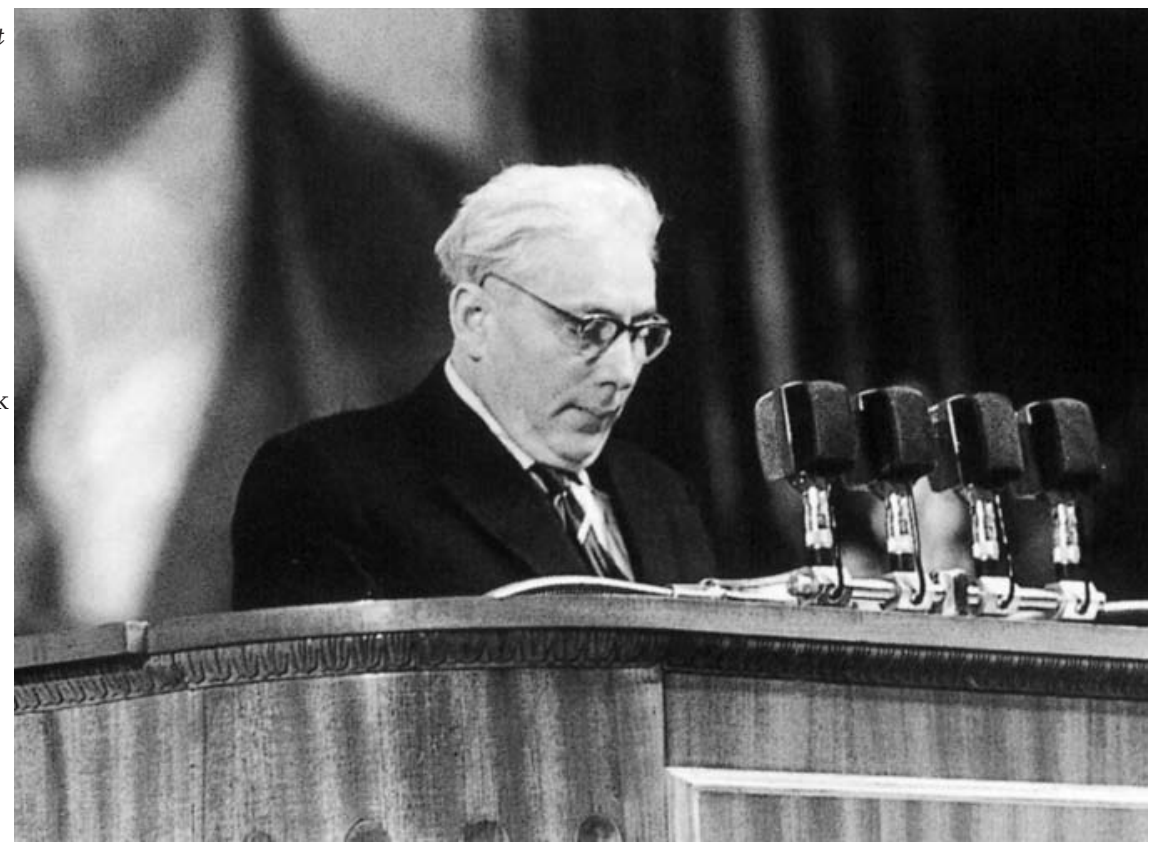

\section{Omdat er iets ging wringen}

Op 3I mei ig 65 wordt de nieuwe nota over het radio- en televisiebeleid gepubliceerd. Daarin staat niets te lezen over zendtijd voor de CPN. Wel echter de zinsnede:

'Aan alle politieke partijen die in de Tweede Kamer vertegenwoordigd zijn, zal met ingang van het nieuwe seizoen (I septemberig65) gelegenheid tot uitzenden worden gegeven'. ${ }^{26}$

In de Tweede Kamer is inmiddels geen enkele partij meer voor het uitsluiten van de CPN, zo blijkt uit het debat over deze nota. Er is wel verschil van mening. De vvD noemt bij monde van Geertsema het toekennen van zendtijd 'een eis van de democratie'. De PvdA is het daar niet mee eens en sluit zich aan bij de meer pragmatische motivatie van minister Vrolijk die 'veranderde inzichten in diverse kringen van het volk' noemt en 'ontwikkelingen in de situatie waarin de verschillende politieke partijen zich aan den volke kunnen vertonen'. Vrolijk: 'Ik geloof dat daar ergens iets gaat wringen aan de begrijpelijkheid van de situatie'. ${ }^{27}$ Slechts één afgevaardigde laat een afwijkend geluid horen. Goedhart (PvdA) betoogt dat met het toekennen van zendtijd aan de CPN de regering in de praktijk zendtijd verleent aan 'het Kremlin, Ulbricht, de Vietcong, Hanoi en Mao Tse Tung. Hoe is de regering op deze zonderlinge gedachte gekomen? ${ }^{28}$ 
Op 3 september 1965 is de eerste radio-uitzending van de CPN, op 20 september komt de partij voor het eerst in eigen zendtijd op de televisie. De Waarheid noteert enthousiaste reacties van bekende persoonlijkheden in die dagen zoals de voetballer Coen Moulijn en de schrijfster Annie M.G. Schmidt. Het D в van de CPN toont geen tekenen van een overwinningsroes, het verslag meldt alleen wat opmerkingen over de vormgeving van de uitzendingen. ${ }^{29}$ De troonrede en de miljoenennota krijgen veel meer aandacht. Wel krijgt Henk Hoekstra dezer dagen fiat voor een interview aan de Haagse Post 'mits er een schriftelijke verklaring vooraf komt dat de tekst voor publicatie kan worden ingezien'. Ook de CPN blijft kennelijk niet onberoerd door de grotere openheid in het politieke klimaat van die dagen.

Tot slot

Vrijheid van meningsuiting is een groot goed in de democratie. Maar hoeveel ruimte geeft een meerderheid aan een minderheid die het vigerende stelsel bestrijdt en bij wie men ditzelfde grote goed niet veilig acht? Dat is de principiële vraag die in deze kwestie domineert en die actueel is gebleven en zelfs aan actualiteit heeft gewonnen na II september 200I.

In de geschiedenis van het aanvankelijk onthouden en later toch toekennen van zendtijd aan de CPN is geen finaal antwoord op deze vraag gekomen van de Nederlandse regering. De principiële kant van de zaak komt af en toe wel aan de orde, maar uiteindelijk domineert toch een pragmatische benadering.

Bij de uitsluiting spelen aanvankelijk politieke en ideologische motieven een hoofdrol. Er is angst voor een (nieuwe) totalitaire overheersing. En er is in de dichotome wereld van dat moment gekozen: voor het Westen, dus tegen het Oosten en tegen ieder die zich daarmee verwant verklaart.

Halverwege de jaren zestig, als de uitsluiting van de CPN wordt opgeheven, is de acute oorlogsdreiging verdwenen. De angst, waar de BvD zonder succes nog steeds op speculeert, heeft plaatsgemaakt voor de hoop op 'vreedzame coëxistentie' van Oost en West, al is de Koude Oorlog nog lang niet afgelopen. En ook de CPN is veranderd. De partij wil niet kiezen in het conflict tussen Moskou en Peking, distantieert zich van het Oostblok en gaat een onafhankelijke, nationalistische koers varen. Tegelijkertijd ziet men ook buiten de communistische beweging de eerste tekenen van afstand ten opzichte van de Verenigde Staten die als 'onze bevrijders' in andere delen van de wereld met geweld hun eigen belangen veilig stellen.

Deze politieke ontwikkelingen hebben ongetwijfeld bijgedragen aan een klimaat waarin er geen meerderheid meer te vinden was voor de scherpslijperij van ouderwetse anticommunisten zoals Goedhart en de mannen van de BvD. Maar rechtstreekse invloed van deze politieke factoren op een nieuw beleid inzake de zendtijd voor politieke partijen is moeilijk aan te wijzen. Typerend is dat de C P N 
heel bewust niet met name genoemd wordt bij de verandering van de regeling. Een principiële politieke discussie over het onderwerp 'uitsluiting van zendtijd' wordt het liefst vermeden, althans door de regering.

Al wordt het dan niet expliciet gezegd, met haar verhullende formuleringen als 'het is niet meer uit te leggen' en 'daar gaat iets wringen' laat de regering wel zien dat men gehoor wil geven aan de roep in de maatschappij om meer openheid en minder bevoogding. De C PN als enige uitsluiten van zendtijd voor politieke partijen zou niet alleen ongewenste aandacht op deze partij vestigen. De uitsluiting past ook niet in een tijd waarin televisie met zijn nieuwe journalistieke vormen $^{30}$ zo veel meer dan voorheen ongecensureerd zichtbaar maakt en waarin steeds meer mensen zich keren tegen regentesk gedrag dat een eigen zelfstandige beoordeling van politiek en politici belemmert. ${ }^{3 \mathrm{I}}$ Een goed gevoel voor de tijdgeest, zou men kunnen zeggen, heeft regering en parlement uiteindelijk doen besluiten om oude bezwaren tegen de CPN opzij te zetten en zonder uitzondering voor alle in het parlement vertegenwoordigde partijen zendtijd ter beschikking te stellen.

\section{Noten}

I Geciteerd door P. Mol, 'Om de democratie te beschermen', in: B.Hogenkamp \& P. Mol, Van beeld tot beeld; de films en televisie-uitzendingen van de CPN 1928-1986, Stichting Film en Wetenschap/ Audiovisueel Archief [nu: Nederlands Instituut voor Beeld en Geluid, Hilversum], Amsterdam I993.

2 Mol, 'Om de democratie te beschermen', p. I34-I35.

3 Idem, p. I36.

4 Idem, p. I37.

5 Idem, p. I4I.

6 J. Bank, 'Televisie verenigt en verdeelt Nederland', in: H. Wijfjes (red.), Omroep in Nederland, vijfenzeventig jaar medium en maatschappij 1919 - 1994, Zwolle I994, p. 94.

7 Bank, 'Televisie verenigt en verdeelt Nederland', p. 97.

$8 \mathrm{Mol}$, 'Om de democratie te beschermen', p.I46.

9 Idem, p. I47. Deze uitspraak moet ook gezien worden tegen de achtergrond van het feit dat de CPN juist in deze tijd de koers verlegt naar een autonome, meer nationale politiek, los van de Sovjet-Unie, omdat de partij weigert positie te kiezen in het conflict Moskou-Peking. Zie: A. Stam, De CPN en haar buitenlandse kameraden, Soesterberg 2004.

Io Minister Bot refereert later ook aan dit standpunt in zijn brief aan de minister-president van I8-9-I963, bij Archiefstukken BvD opgenomen in het CPN-archief (IISG Amsterdam), nr. I769.

II CPN-archief, nr. 324 .

I2 CPN-archief, nr. 324 .

I3 CPN-archief, nr. 325 .

I4 CPN-archief, nr. 325 .

I5 Archiefstukken BVD opgenomen in het CPN-archief, nr. I769.

I6 Brief van de minister van o K\&W aan de minister-president dd. I8-9-I963 bij Archiefstukken BVD opgenomen in het CPN-archief, nr. I769.

I7 Archiefstukken BVD opgenomen in het CPN-archief, nr. I769.

I8 Archiefstukken BVD opgenomen in het CPN-archief, nr. I769.

I9 Notulen ministerraad, II oktober I963, Nationaal Archief Den Haag. 
20 Notulen ministerraad, 25 oktober I963, Nationaal Archief Den Haag.

2I Brief van minister Bot dd. I8 februari I965, bij Archiefstukken BVD opgenomen in het CPN-archief, nr. 1769 .

22 BvD-notitie dd. 25-2-1965. Archiefstukken Bvd opgenomen in het CPN-archief, nr. I769.

23 Notulen ministerraad, 7 mei 1965, punt I3, Nationaal Archief Den Haag.

24 Notulen ministerraad, 2I mei I965, Nationaal Archief Den Haag.

25 Notulen ministerraad, 28 mei 1965, Nationaal Archief Den Haag.

26 Geciteerd door Mol, 'Om de democratie te beschermen', p. I5I.

27 Geciteerd door Mol, 'Om de democratie te beschermen', p. I52.

28 Geciteerd door Mol, 'Om de democratie te beschermen', p. I53.

29 CPN-archief, nr. 325.

30 Zie noot 7; zie ook H. Beunders over taboedoorbrekende actualiteitenrubrieken en discussieprogramma's in: 'Nieuws, actualiteiten en informatie op de televisie', in: Wijfjes (red.), Omroep in Nederland, p. I55.

3I Bank, 'Televisie verenigt en verdeelt Nederland', in: Wijfjes (red.), Omroep in Nederland, p. Ior, besluit zijn artikel over de rol van de televisie als volgt: 'Het massamedium was tenslotte begroet als een "eye opener", als een mogelijkheid tot openbaring en democratisering van informatie en cultuur. In die hoedanigheid werd het ook een instrument tot een tamelijk intensieve overdracht van tegengestelde meningen en normconflicten. De emotionele reacties zijn een graadmeter van de culturele schokken, die er het gevolg van waren. Televisie is niet meer weg te denken uit hetgeen de tijdgenoten in de jaren zestig heeft bewogen.' 